
\title{
R Reserach S Suare \\ Burden and associated factors of Scabies outbreak in Guna-begemidir district, south Gondar, Amhara, Ethiopia, 2018
}

Temesgen Anteye Adamu ( $\sim$ anteye691@gmail.com )

Amhara National Regional Health Bureau

Adino Tesfahun Tsegaye

University of Gondar

Research article

Keywords: Guna-begemidir district, northwest Ethiopia, Risk factors, scabies outbreak

Posted Date: January 15th, 2020

DOI: https://doi.org/10.21203/rs.2.20900/v1

License: (c) (i) This work is licensed under a Creative Commons Attribution 4.0 International License.

Read Full License 


\section{Abstract}

\section{Background}

Scabies is an infestation of the skin by the human itch mite ( Sarcoptes scabiei var. hominis). The parasite is found worldwide and affects people of all races and social classes. Studies shows that the prevalence of scabies is far different as $0.2 \%$ in developed countries up to $24 \%$ in developing countries. Ethiopia also reports scabies outbreak frequently since 2017. Recent studies show that the attack rate was $25 \%$ in Gondar city in Yekolo-temaries and $11 \%$ at Badewacho District, Southern Ethiopia.

\section{Methods}

A community based unmatched case-control (1:2 ratios) study was conducted in guna-begemidir district, using collected scabies line listed data and face to face interview to assess risk factors from January to February 2018 with sample size of 156 cases and 312 control. The data were collected using structured questionnaire, and analyzed using SPSS version 22 statistical software. Odds Ratios (OR), P value and 95\% Confidence interval (Cl) was computed to determine associated factors.

Result

A total of 4269 scabies case were reported from the district, attack rate of $7.9 \%$. Of those cases 2254 (52.8\%) were males. 10 (52.6\%) kebeles were affected by the outbreak. The attack rate varies by kebeles which ranges from $0.88 \%$ to $25.5 \%$. The highest attack rate was in mena-medihanealem kebele which is $25.5 \%$. Sleeping with Scabies Patients, washing with scabies patients in the past 6 months, putting of cloths with diseased patient cloths and Household daily water consumption were significantly associated with scabies diseases on multivariable analysis.

\section{Conclusion and recommendation}

Scabies is public health problem in the district. Due to delayed detection and response, the disease was highly disseminated mainly because of drug shortage throughout the region. We recommend enhancing, strong ongoing active case surveillance of scabies; health education \& availing drugs to all health facilities and do more on the above significant variables.

\section{Background}

Scabies is an infestation of the skin by the human itch mite (Sarcoptes scabiei var. hominis). Sarcoptes scabiei is an ectoparasitic mite that burrows under the skin of mammalian hosts [1]. Scabies can develop anywhere on the skin. The distribution of scabies usually involves the sides and webs of the fingers, the flexor aspects of the wrists, the extensor aspects of the elbows \& waist. [2, 3]. Symptoms of scabies typically begin three to six weeks after primary infestation. However, in patients who have previously been infested with scabies, symptoms usually begin within one to three days after re-infestation, presumably because of prior sensitization of the patient's immune system. Infested persons can transmit scabies, 
even if they do not have symptoms, until they are successfully treated and the mites and eggs are destroyed [2-4].

The parasite is found worldwide and affects people of all races and social classes [5]. scabies has been added to WHO`s list of neglected tropical diseases, affects very large number of people unlike other NTDs. It occurs widely in temperate areas and high where overcrowding and poverty coexists [6]. Scabies outbreak is highly coasty to control and is widely disseminate if not properly managed. It occurs in all age groups and all ethnic groups, the only difference is due to overcrowding, housing, socio economic and behavioral factors. But highly affects children, peoples of poor personal hygiene, peoples live in overcrowding \& slum areas and peoples affected by drought and war. Its worldwide occurrence with epidemics during war, famine and overcrowding is responsible for an estimated 300 million people [5].

The prevalence of scabies is considered to be low in the general population in most industrialised nations. It is usually only considered to be a disease of public health importance in indigenous populations, the elderly, and immune-compromised individuals such as those living with HIV/AIDS. The prevalence and complication make it significant public health problem in developing countries. Hence, scabies and other skin infections (with the exception of leprosy) remain largely overlooked as a public health issue in developing countries. Studies shows that the prevalence of scabies is far different as $0.2 \%$ in developed countries up to $24 \%$ in developing countries [7]. By the end of 20th century the global prevalence became 5\%, but become increased up to $30 \%$ during war [5]. Sub-Saharan Africa has prevalence of $1.3 \%-17 \%$ [7]. It accounts prevalence of $9.7 \%$ in south East Asia, $13 \%$ in India, $6.1 \%$ in Burkina Faso school children [7, 8].

Ethiopia also reports scabies outbreak frequently in Amhara, Oromia, SNNP and Tigray region since 2017 [9]. WHO states that in 1992 prevalence of scabies in 5-16 years children was $17 \%$ and from 1995 up to 1997 it became $4 \%$ but it was the 4th top diseases of the country [7]. The 2008 national health and nutrition survey also shows the prevalence was 5.5\% [10]. In 2015 scabies reemerge again in Oromia, SNNP and Tigray region and the prevalence became 15\% in some districts of affected regions [3]. Studies done in Gondar city in Yekolo-temaries shows that the prevalence is $10 \%$ and the overall attack rate was 22.5\% [11]. On other studies done in school children of southern Ethiopia shows that the prevalence was $5.5 \%$. Recent studies in south Gondar, tachgayint district shows the prevalence was $2.5 \%$. but the overall attack rate was $9.4 \%$, with highest age specific attack rate in above 45 years age group which was $24.8 \%$ [12]. Likewise Studies done in East Badewacho District, Southern Ethiopia states the prevalence \& attack rate was $11 \%$ with highest age specific attack rate between 5 and 14 years which was $26.3 \%$ [13].

Different studies in different areas verifies different significant factors. Studies done in East Badewacho District, Southern Ethiopia states that age, family size, sleeping with scabies patients and cloth contact with scabies patient are significantly associated with scabies [13]. On the other studies Economic status, age, educational status, hygiene, contact with scabies patients, bed/cloth sharing, frequency of showering, detergent use, frequency of cloth changing and water availability are major factors which are significantly associated with scabies development in different studies [10-12, 14-16]. In addition to 
those, the Ethiopian interim guide line states that knowledge about the diseases transmission treatment and prevention, religion and occupation may alter the disease prevalence [1]. There for this study aims to investigate the scabies outbreak, to describe the outbreak by time, place and person, to identify the possible risk factors of the outbreak and provide possible interventions to control and prevent the disease in Guna-begemidir district, Northwest Ethiopia, February 2018

\section{Methods}

\section{Study design and period}

Unmatched case control study design was conducted in Guna-begemidir district from January 30February 25/2018.

\section{Study setting}

Guna-begemidir District is one of the Districts found in south Gondar Zone, located $35 \mathrm{~km}$ from debretabor town, $137 \mathrm{~km}$ from the Regional town bahirdar formed as a district on July 2017. The District has catchment area of 51373.2 hectare with altitude range of $1200-4220 \mathrm{~m}$ above sea level. The district has weather condition of $17 \%$ kola, $46 \%$ weynadega, $32 \%$ Dega and $5 \%$ Wurch. The total population of the District was 100727 of which females constitute 50464 (50.1\%). Districts that share boundaries with guna-begemidir District are Lay Gayint at the North, Farta the South, Estie District at the East and Ebinat District at the West. The District has 19 Kebeles, 04 HCs, 21 HPs, 79 health care providers, 79 other nonhealth staffs and $37 \mathrm{HEWs[17].}$

\section{Target population}

All populations living in Guna-begemidir district

\section{Study population}

Populations living in the assessed six kebeles of Guna-begemidir district

\section{Sampling and sample size determination}

We calculated the sample size using Epi Info 7 for unmatched case control study with an assumption of $95 \% \mathrm{Cl}, 90 \%$ power, OR of 2, ratio of controls to cases $2: 1$ and taking $26.6 \%$ of controls shared close with ill person from studies done in Gondar town among Yekolo-temaries[11]. The total calculated sample was 156 case and 312 controls. Cases were selected using simple random sampling technique from the registered of 420 cases in the line list document where identified by teams from zonal health department, district health office and health center staffs during verification, identified by Ethiopian interim guideline for multisectoral scabies outbreak guideline using suspected case definition. Controls were enrolled from 
the family of cases or villages where cases were enrolled without the history of scabies during the study period and if no control from family we select from neighboring villages.

\section{Data collection methods}

Data was collected from cases and controls by moving house to house of exposed villages from January 30 -February 25/2018. Participants were interviewed using structured questionnaires and primary data was collected from respondents by the investigator. Data of children who were unable to respond was taken from their mothers (care givers). A total of 156 cases and 312 controls were interviewed to assess their sociodemographic and other variables and exposure status.

\section{Data entry and analysis}

Data was entered by using SPSS version 22 and analyzed by MS excel 2013, SPSS version 22 and Arc Gis10.3. Descriptive analysis was performed for sociodemographic characteristics and other risk factors. We explained results as frequencies, proportions, rates, mean /median and standard deviations. Risk factors were identified statically by computing OR with $95 \% \mathrm{Cl}$, by bivariate and multivariable logistic regression analysis. Variables having $\mathrm{p}$ value of less than 0.2 were entered to multivariable analysis to identify significant variables. Variables with $p$ value less than 0.05 with corresponding $95 \% \mathrm{Cl}$ were considered as significantly associated in multivariable logistic regression.

\section{Inclusion and Exclusion criteria}

\section{Cases}

Any resident of Guna-begemidir district who had signs and symptoms of scabies using suspected case definition

\section{Controls}

Any resident of Guna-begemidir district during the study living in the family or village of neighboring cases that did not develop signs and symptoms of scabies.

\section{Case Definition}

- Suspected case: A person with signs and symptoms consistent with scabies.

- Confirmed case: A person who has a skin scraping in which mites, mite eggs or mite feces have been identified by a trained health care professional.

\section{Operational definitions}

Contact: A person without signs and symptoms of scabies who had direct contact (particularly prolonged, direct, skin-to-skin contact) with a suspected or confirmed case in the two months preceding the onset of scabies signs and symptoms in the case. 
Infrequent changing of clothes: Those who wear same cloth for more than one week without washing and changing

General Knowledge about scabies - those who answered at least one transmission, prevention mechanism and or treatment of scabies.

Mild case - patients having less than 6 skin lesions

Moderate - patients having 6-10 lesions

Severe - patients having greater than 11 skin lesion and or has crusted scabies.

Attack rate - percentage of total new cases identified divided by risk population

Monthly income - classified based on quartile as in four classes.

\section{Hypothesis}

The null hypothesis was stated as there is no association between socio demographic variables, access to water, frequency of bathing, washing and changing clothes and other factors with counteracting scabies.

\section{Result}

\section{Descriptive Epidemiology}

Even though the outbreak was started since July 2017, they reported late on October 11/2017. Team from zone confirmed the existence of scabies outbreak in the area. Investigation with semi intervention was started on February 2018. Because of shortage of drugs throughout the region, intervention was done primarily on education about personal hygiene rather than early detection and treatment until June 2018. Even though treatment was not given, cases became decline after March 2018 as seen in the figure below. 4269 scabies case were reported from the district with attack rate of $7.9 \%$.

From the total 4269 cases 2254 (52.8\%) were males. 35.1\% were below 15 years and $31.6 \%$ were above 45 years with age specific attack rate of $6.49 \%$ and $26.29 \%$ respectively. The age specific attack rate was higher for people older than 45 years. 
Table 1

Age distribution of scabies patients in Guna-begemidir district, South Gondar, Northwest Ethiopia, 2018

\begin{tabular}{|c|c|c|c|c|c|c|}
\hline No & Age & Risk population & cases & Percent & Attack rate & Remark \\
\hline 1 & $<5$ years & 7346 & 388 & 9.09 & $5.28 \%$ & \\
\hline 2 & $5-14$ years & 15784 & 1112 & 26.05 & $7.05 \%$ & \\
\hline 3 & $15-44$ years & 25998 & 1422 & 33.31 & $5.45 \%$ & \\
\hline 4 & $>=45$ years & 5124 & 1347 & 31.55 & $26.29 \%$ & \\
\hline Total & & 54252 & 4269 & & $7.87 \%$ & \\
\hline
\end{tabular}

Out of total 19 Kebeles in the district seven (36.8\%) were affected by the outbreak. The attack rate varies by kebeles which ranges from $0.83-24.7 \%$. The highest attack rate was in mena-medihanealem kebele. During the study period a total of 156 cases and 312 controls were interviewed using the standardized questionnaire. From the total study subjects $237(50.6 \%)$ were males. The mean age of patients was 33.29 years with standard deviation of \pm 17.61 years.

Of total participants, $94.9 \%$ were Orthodox Christianity followers. $41.9 \%$ of total respondents used less than 25 litter per person per day. From the total 156 cases interviewed $49.4 \%$ were males. $79 \%$ of cases were developed itching first. In $99 \%$ of cases itching became intense at night. $55.8 \%$ and $39.7 \%$ of case's mostly affected body part were hand and wrist respectively. $27.6 \%$ of cases were infected repeatedly. 
Table 2

Frequency distribution for sociodemographic variables of scabies outbreak in Guna-begemidir district, south Gondar, Northwest Ethiopia, 2018

\begin{tabular}{|c|c|c|c|c|}
\hline No & \multicolumn{2}{|l|}{ Variables } & $\begin{array}{l}\text { Case (\%) } \\
n=156\end{array}$ & $\begin{array}{l}\text { Control (\%) } \\
n=312\end{array}$ \\
\hline \multirow[t]{4}{*}{1} & \multirow[t]{4}{*}{ Age of respondents } & $<5$ years & $5(3.2)$ & $9(2.9)$ \\
\hline & & $5-14$ years & $35(22.4)$ & 19(6.1) \\
\hline & & $15-44$ years & $77(49.4)$ & $206(66)$ \\
\hline & & $>=45$ years & $39(25)$ & $78(25)$ \\
\hline \multirow[t]{2}{*}{2} & \multirow[t]{2}{*}{ Sex } & Male & $77(49.4)$ & $160(51.3)$ \\
\hline & & Female & $79(50.6)$ & 152(48.7) \\
\hline \multirow[t]{5}{*}{3} & \multirow[t]{5}{*}{ Occupation } & Farmer & 92((59) & $180(57.7)$ \\
\hline & & Trader & $4(2.6)$ & $27(8.7)$ \\
\hline & & House wife & $8(5.1)$ & $22(7.1)$ \\
\hline & & Student & $48(30.8)$ & $83(26.6)$ \\
\hline & & Not applicable & $4(2.6)$ & $0(0)$ \\
\hline \multirow[t]{2}{*}{4} & \multirow[t]{2}{*}{ Religion } & Orthodox & 148(94.9) & $296(94.9)$ \\
\hline & & Muslim & $8(5.1$ & $16(5.1)$ \\
\hline \multirow[t]{5}{*}{5} & \multirow[t]{5}{*}{ Marital Status } & Single & $31(19.9)$ & $77(24.7)$ \\
\hline & & Married & $117(75)$ & $203(65.1)$ \\
\hline & & divorced/separated & $0(0)$ & $6(1.9)$ \\
\hline & & Widowed & $4(2.6)$ & $8(2.6)$ \\
\hline & & Not applicable & $4(2.6)$ & $18(5.8)$ \\
\hline \multirow[t]{5}{*}{6} & \multirow[t]{5}{*}{ Educational status } & Primary & $85(54.5)$ & $142(45.5)$ \\
\hline & & Secondary & $0(0)$ & $39(12.5)$ \\
\hline & & collage and above & $0(0)$ & 19(6.1) \\
\hline & & Illiterate & $69(44.2)$ & $112(35.9)$ \\
\hline & & Not applicable & $2(1.3)$ & $0(0)$ \\
\hline \multirow[t]{2}{*}{7} & \multirow[t]{2}{*}{ Monthly Income } & $\leq 2170$ birr & $88(56.41)$ & $35(11.22)$ \\
\hline & & $2171-3950$ birr & 19(12.18) & $93(29.81)$ \\
\hline
\end{tabular}




\begin{tabular}{|llll|}
\hline No Variables & $\begin{array}{l}\text { Case (\%) } \\
\mathbf{n = 1 5 6}\end{array}$ & $\begin{array}{l}\text { Control (\%) } \\
\mathbf{n = 3 1 2}\end{array}$ \\
\hline $3951-5452$ birr & $24(15.38)$ & $92(29.49)$ \\
\hline$>5452$ birr & $25(16.03)$ & $92(29.49)$ \\
\hline
\end{tabular}


Table 3

Frequency distribution for scabies related variables in Guna-begemidir district, south Gondar, Northwest Ethiopia, 2018

\begin{tabular}{|c|c|c|c|c|}
\hline No & \multicolumn{2}{|l|}{ Variables } & \multirow{2}{*}{$\begin{array}{l}\text { case }(\%) n \\
=156 \\
107(68.6)\end{array}$} & \multirow{2}{*}{$\begin{array}{l}\text { control (\%) n } \\
=312\end{array}$} \\
\hline 1 & Family number & $<6$ children & & \\
\hline & & $>=6$ children & $49(31.4)$ & $98(31.4)$ \\
\hline \multirow[t]{2}{*}{2} & \multirow[t]{2}{*}{ Affected family number } & No & $67(42.9)$ & $173(55.4)$ \\
\hline & & Yes & $89(57.1)$ & $139(44.6)$ \\
\hline \multirow[t]{2}{*}{3} & \multirow[t]{2}{*}{ Sleeping with Scabies Patients } & No & $63(40.4)$ & $233(74.7)$ \\
\hline & & Yes & $93(59.6)$ & $79(25.3)$ \\
\hline \multirow[t]{2}{*}{4} & \multirow[t]{2}{*}{ Cloth Sharing with Others } & No & $68(43.6)$ & $169(54.2)$ \\
\hline & & Yes & $88(56.4)$ & $143(45.8)$ \\
\hline \multirow[t]{3}{*}{5} & \multirow[t]{3}{*}{ Frequency of showering } & Weekly & $0(0)$ & $2(0.6)$ \\
\hline & & Every other week & 19(12.2) & $269(86.2)$ \\
\hline & & Monthly \& above & $137(87.8)$ & $41(13.1)$ \\
\hline \multirow[t]{2}{*}{6} & \multirow[t]{2}{*}{ Detergent of Showering } & Water & $86(55.1)$ & $141(45.2)$ \\
\hline & & Water \& soap & $70(44.9)$ & $171(54.8)$ \\
\hline \multirow[t]{2}{*}{7} & \multirow{2}{*}{$\begin{array}{l}\text { Washing with scabies patients in the } \\
\text { past } 6 \text { months }\end{array}$} & No & $57(36.5)$ & $231(74)$ \\
\hline & & Yes & $99(63.5)$ & $81(26)$ \\
\hline \multirow[t]{2}{*}{8} & \multirow{2}{*}{$\begin{array}{l}\text { Sharing bedding or cloth with scabies } \\
\text { patient }\end{array}$} & No & $55(35.3)$ & $231(74)$ \\
\hline & & Yes & $101(64.7)$ & $81(26)$ \\
\hline \multirow[t]{3}{*}{9} & \multirow[t]{3}{*}{ Frequency of cloth washing } & Weekly & $10(6.4)$ & $50(16)$ \\
\hline & & Every other week & $36(23.1)$ & 103(33) \\
\hline & & Monthly \& above & $110(70.5)$ & 159(51) \\
\hline \multirow[t]{2}{*}{10} & \multirow{2}{*}{$\begin{array}{l}\text { Putting of cloths with diseased patient } \\
\text { cloths }\end{array}$} & No & $54(34.6)$ & $234(75)$ \\
\hline & & Yes & $102(65.4)$ & $78(25)$ \\
\hline \multirow[t]{2}{*}{11} & \multirow[t]{2}{*}{ Frequency of cloth changing } & $\begin{array}{l}\text { every other day \& } \\
\text { below }\end{array}$ & $13(8.3)$ & $34(109)$ \\
\hline & & Weekly & $0(0)$ & $0(0)$ \\
\hline
\end{tabular}




\begin{tabular}{|c|c|c|c|c|}
\hline No & Variables & & $\begin{array}{l}\text { case }(\%) n \\
=156\end{array}$ & $\begin{array}{l}\text { control (\%) } n \\
=312\end{array}$ \\
\hline & & above weekly & 143(91.7) & 278(89.1) \\
\hline \multirow[t]{2}{*}{12} & Household daily water consumption & $\begin{array}{l}<25 \\
\text { litter/person/day }\end{array}$ & 115(73.7) & $81(26)$ \\
\hline & & $\begin{array}{l}>=25 \\
\text { litter/person/day }\end{array}$ & $41(26.3)$ & 231(74) \\
\hline \multirow[t]{2}{*}{13} & Knowledge about scabies & No & $80(51.3)$ & $160(51.3)$ \\
\hline & & Yes & $76(48.7)$ & 152(48.7) \\
\hline
\end{tabular}

From total interviewed cases $26.9 \%$ were severe cases. 136 (87.2\%) of cases had skin lesion, $82(52.6 \%)$ had crusted scabies and 87 (55.8\%) had skin sore. $26.9 \%$ were severe cases and $38.5 \%$ were mild cases.

\section{Analytic analysis}

After doing bivariable binary logistic regression analysis, the following ten variables were entered to multivariable binary logistic regression analysis. Whereas on multivariable binary logistic regression analysis sleeping with Scabies patients, washing with scabies patients in the past 6 months, putting of cloths with diseased patient cloths and household daily water consumption became significantly associated variables for the development of scabies diseases. 
Table 4

Result for multivariable analysis of factors for development of scabies of Guna-begemidir district, 2018

\begin{tabular}{|c|c|c|c|c|c|}
\hline \multirow[t]{2}{*}{ Variables } & & \multicolumn{2}{|c|}{ Case Status } & \multirow[t]{2}{*}{ COR $(95 \% \mathrm{Cl})$} & \multirow[t]{2}{*}{ AOR $(95 \% \mathrm{Cl})$} \\
\hline & & $\begin{array}{l}\text { Case } \\
(n= \\
156)\end{array}$ & $\begin{array}{l}\text { Control } \\
(n=312)\end{array}$ & & \\
\hline \multirow[t]{4}{*}{ Age } & $<5$ yrs & 5 & 9 & & \\
\hline & $5-14$ yrs & 35 & 19 & $3.32(0.97,11.32)$ & $1.23(0.25,5.98)$ \\
\hline & $\begin{array}{l}15-44 \\
\text { yrs }\end{array}$ & 77 & 206 & $0.67(0.22,2.07)$ & $0.25(0.06,1.07)$ \\
\hline & $>=45 \mathrm{yrs}$ & 39 & 78 & $0.90(0.28,2.87)$ & $0.25(0.05,1.14)$ \\
\hline \multirow[t]{2}{*}{ Affected Family Number } & No & 64 & 173 & & \\
\hline & Yes & 89 & 139 & $1.65(1.12,2.44)$ & $1.72(0.98,3.01)$ \\
\hline \multirow{2}{*}{$\begin{array}{l}\text { Sleeping with Scabies } \\
\text { Patients }\end{array}$} & No & 63 & 233 & & \\
\hline & Yes & 93 & 79 & $4.35(2.89,6.55)$ & $\begin{array}{l}3.70(2.08,6.61) \\
\star\end{array}$ \\
\hline \multirow{2}{*}{$\begin{array}{l}\text { Cloth Sharing with } \\
\text { Others }\end{array}$} & No & 68 & 169 & & \\
\hline & Yes & 88 & 143 & $1.53(1.04,2.25)$ & $0.99(0.54,1.83)$ \\
\hline \multirow[t]{2}{*}{ Detergent of Showering } & Water & 86 & 141 & & \\
\hline & $\begin{array}{l}\text { Water \& } \\
\text { soap }\end{array}$ & 70 & 171 & $0.67(0.46,0.99)$ & $0.581(0.33,1.02)$ \\
\hline \multirow{2}{*}{$\begin{array}{l}\text { Washing with scabies } \\
\text { patient in the past } 6 \\
\text { months }\end{array}$} & No & 57 & 231 & & \\
\hline & Yes & 99 & 81 & $4.95(3.28,7.48)$ & $\underset{\star}{4.05}(2.30,7.13)$ \\
\hline \multirow{2}{*}{$\begin{array}{l}\text { Sharing bedding with } \\
\text { scabies patient }\end{array}$} & No & 55 & 231 & & \\
\hline & Yes & 101 & 81 & $5.24(3.46,7.93)$ & $1.74(0.90,3.37)$ \\
\hline \multirow{2}{*}{$\begin{array}{l}\text { Putting of cloths with } \\
\text { patient cloths }\end{array}$} & No & 54 & 234 & & \\
\hline & Yes & 102 & 78 & $5.67(3.73,8.61)$ & $\begin{array}{l}4.71(2.64,8.42) \\
\star\end{array}$ \\
\hline \multirow{2}{*}{$\begin{array}{l}\text { Household daily water } \\
\text { consumption }\end{array}$} & $<25$ Lit/P & 115 & 81 & & \\
\hline & $\begin{array}{l}>=25 \\
\mathrm{Lit} / \mathrm{P}\end{array}$ & 41 & 231 & $0.13(0.08,0.19)$ & $\underset{\star}{0.06(0.03,0.12)}$ \\
\hline
\end{tabular}




\begin{tabular}{|llllll|}
\hline $\begin{array}{l}\text { Frequency of cloth } \\
\text { washing }\end{array}$ & $\begin{array}{l}\text { Weekly \& } \\
\text { below }\end{array}$ & 10 & 50 & & \\
& $\begin{array}{l}\text { Every } \\
\text { other } \\
\text { week }\end{array}$ & 36 & 103 & $1.75(0.80,3.80)$ & $0.71(0.25,2.02)$ \\
\hline & $\begin{array}{l}\text { Monthly } \\
\text { and above }\end{array}$ & 110 & 159 & $3.46(1.68,7.12)$ & $1.51(0.57,3.95)$ \\
\hline *P value $<0.05$ & & & & & \\
\hline
\end{tabular}

\section{Discussion}

Out of 19 kebeles $36.8 \%$ were scabies affected kebeles which are nearby of Ebinat district, the 2016/7 highly affected district. Highest attack rate was recorded in mena-medihanealem, menadique and gentegna district which was $25.5 \%, 19.67 \%$ and $4.55 \%$ respectively. This may be due to frequent contact in different public ceremonies and day to day activity with the former affected district, Ebinat district. $27.6 \%$ of cases were infected repeatedly. This may be due to delayed of treatment and prevention and control activity in the district which leads frequent transmission through contact

The prevalence of scabies in Guna-begemidir district was 4.2\%. It was parallel with prevalence in different district of SNNP, Amhara, Oromia and Tigray region in 2015 (5\%) [10]. But was higher than prevalence of Tachgayint district, Northwest Ethiopia, which was 2.67\% [12], kicha-bira district of Gambela region $(0.4 \%)$ [15] and dogatemben district of Tigray region (0.03\%) [16]. This might be due to delay in investigation and prevention and control activity in our study area. But it was lower than Studies done in East Badewacho District, Southern Ethiopia which was 11\% [13]. Sociodemographic difference might be the possible reason for the difference. The overall attack rate of scabies in Guna-begemidir district was $7.9 \%$. it was lower than studies done among Yekolo-temaries in st.lideta church, Gondar which was $22.5 \%$ [11] and studies done in tachgayint district (9.4\%)[12]. This may be due to that in Yekolo-temaries usually frequent contact and poor hygiene is observed and in tach Gayint district during the outbreak period, there were drought disaster, due to this it was difficult to take personal hygiene and treatment for disease compared from guna. But was higher than studies done in Tigray region dogatemben district which was $0.069 \%[16]$. This may be due to the reason that our study area there were frequent contact in the nearby affected kebeles and delayed in investigation and prevention and control activity, but nothing known about dogatemben. Age specific attack rate was higher among age $>45$ years. This is inconsistent with studies done in badewacho district, southern Ethiopia [13], kachbira district of kembata zone [15] and Tigray, dogatemben district [16] which was more in 15-18, 5-14 and less than 5 years respectively. But is similar to studies done in tachgayint [12]. This may be due to socio demographic factors.

In multivariable analysis individuals who sleep with scabies patient, washing with scabies patients in the past 6 months, putting of cloths with diseased patient cloths and Household daily water consumption were significant predictors for scabies. The odds of developing scabies for Individuals who sleep with scabies patient were 3.7 times higher than those who did not sleep with scabies patients (AOR $=3.70$; 
$95 \% \mathrm{Cl}$ 2.075-6.607). This was consistent with studies done in kicha-bira district of Gambela region $(A O R=19.6 ; 95 \% \mathrm{Cl} 9.3-41.5)$ [15] and studies done among Yekolo-temaries in st.lideta church [11]. Studies done in East Badewacho District, Southern Ethiopia also were in line with our study (AOR = 12.4; 95\% $\mathrm{Cl} 3.05-50.9$ ) [13]. This is due to close contact with diseased patients through sleeping together. The odds of developing scabies for Individuals who washed with scabies patients in the past six months were also four times higher than their counterpart $(A O R=4.0595 \% \mathrm{Cl} 2.301-7.127)$. This was also similar with studies done in Kicha-bira District, SNNP region (AOR 146.71, 95\% Cl 54.3-396.6) [15]. The odds of developing scabies for Individuals who put cloths with diseased patients were 4.7 times higher than those who had no contact ( $A O R=4.7195 \% \mathrm{Cl} 2.638-8.421)$. This was also in line with studies done among Yekolo-temaries in st.lideta church $(\mathrm{COR}=2.76,95 \% \mathrm{Cl}=1.04-7.41)[11]$ and studies done in tachgayint ( $\mathrm{AOR}=10.8,95 \% \mathrm{Cl} 5.2-22.4)$ [12]. This is also due to cloth contacts with water inaccessibility through the fact that moving of louses from patient's cloth to others. The odds of developing scabies for Individuals who had daily water consumption of $>25$ litter per person per day were 0.94 times lower than those who used less than 25 litter (AOR $0.0695 \% \mathrm{Cl} 0.033-0.120$ ). This is in line with the FMOH and CDC scabies interim guideline recommendation $[1,2]$. This may be due to that individuals having more water has the advantage to protect their personal hygiene like washing cloths frequently, washing hands and showering regularly which are major preventive way of the diseases $[1,6,7]$

\section{Conclusion}

In this study attack rate was high, those aged peoples were highly affected. Scabies surveillance was poor in the district. No drug was available in the district for scabies treatment. Sleeping with scabies patient, washing with scabies patient, cloth contact with scabies patient and daily water consumption were significantly associated with scabies diseases development. Scabies is public health problem in the district still now. Due to delayed detection and response, the disease transmitted among many people especially because of drug shortage throughout the region. There fore availing all the needed drugs for early treatment, improve their hygiene practices and living conditions through communication, information and education, enhancing strong ongoing active case surveillance, health education on treatment and prevention of scabies in the community and improve water tracking and water storage at critical service points are recommended.

\section{Intervention undertaken}

Routine surveillance system was done and closely followed at each level on a daily and weekly bases from starting of investigation up to June 2018. Health education was given for the community and students in school. Cases with secondary infections was treated with antibiotics accordingly. Scabies management technical guideline in both hard and soft copies was distributed to the district health office as well as the PHEM focal persons and health centers during investigation period. Training were also given to PHEM focal persons and health center health officers based on the National Guideline of scabies for one day on March 2018. 


\section{Abbreviations}

CDC:Center for Diseases Control and prevention, EFETP:Ethiopian Field Epidemiology Training Program, EHNRI:Ethiopian Health and Nutrition Research Institute, PHCU:Primary Health Care Unit, PHEM:Public Health Emergency Management

\section{Declarations}

\section{Ethics approval and consent to participate}

Ethical clearance was obtained from the ethical review committee of the University of Gondar, Institute of Public Health, and formal permission letter was also written to the district from Amhara Region Public Health Institute. Letter was also written to district health office from south Gondar health department. After the objective of the study was explained, verbal consent was obtained from participants and from parents where the study participants were children before interviewed. The right of participants not to participate or withdraw from the study at any time without any precondition was disclosed. Moreover, the confidentiality of information obtained was guaranteed by using code numbers rather than personal identifiers and by keeping the questionnaire locked.

\section{Consent for publication}

Not applicable.

\section{Availability of data and materials}

Data will be available at the corresponding author upon needed.

\section{Competing interests}

The authors declare that they have no competing interest.

\section{Funding}

No funding was obtained for this study.

\section{Authors contributions}

TA conducted the study, coordinated data collection, performed statistical analysis, and drafted the manuscript. AT participated in the design and tool development, performed statistical analysis, and drafted the manuscript. All authors read and approved the final manuscript.

\section{Source of map}

The map is our own, we were done using Arc GIS 10.3 with our Scabies case data. 


\section{STROBE Guidelines}

Not applicable/ not used

\section{Acknowledgments}

We acknowledged the study participants, data collectors, supervisors and District health office staffs for their commitment to take part in the study.

\section{References}

1. FMOH, Interim guideline for multi sectoral scabies outbreak emergency response. Dec 2015, FMOH: Ethiopia.

2. CDC, scabies fact sheet: outbreaks in institutional settings, Global Health. 2012.

3. FMOH, Scabies Outbreak Preparedness and Response Plan Dec, 2015: Ethiopia.

4. JUCS, Guideone risk resource for health care scabies fact sheet: outbreaks in institutional settings, West Des Moines, lowa 50265. 2012.

5. http://infection.thelancet.com December 2006. 16.

6. Http: // the lancet, global health scabies joins-list-who-NTD.

7. WHO, epidemiology and management of common skin diseases in children in developing countries. 2005.

8. Harmen, S.P., The prevalence and impact of the co-morbidity of scabies and other neglected tropical diseases in two countries in the Asia-Pacific region. Professional Doctorate (Research) thesis, James Cook University. . 2009.

9. UNICIEF, humanitarian situation report of Ethiopia. 2017.

10. Hall A, K.T., Demssie T, eta, National health and nutrition survey of school children in Ethiopia. Tropmed int health. 2008. 13: p. 1518-1526.

11. Zeyneba J, A.F., Habtamu Y, etal, Scabies Outbreak Investigation among "Yekolo Temaris" in Gondar Town, North Western Ethiopia November 2015.

12. A, M., Scabies Outbreak Investigation in Tach Gaynt District, South Gondar Zone, Amhara Region, ethiopia. June 2015.

13. Jarso S., Y.H., Achamyelesh G., Scabies outbreak investigation and risk factors in East Badewacho District, Southern Ethiopia: October 2016.

14. Walker SL, L.E., De Sario V, etal, The prevalence and association with health related quality of life of tungiasis and scabies in school children in southern Ethiopia Plos Negl trop dis, 2017. 11(8).

15. G., M., Scabies Outbreak Investigation, Kacha Birra District, Kembata Tembaro Zone, SNNP region, Ethiopia. Nov 2016.

16. H., I., Investigation of Scabies Outbreak South-East Zone, Tigray Regional State, Ethiopia. 2016.

17. office, G.b.d.h., District health office 6 month report. Jan 2018. 
Figures

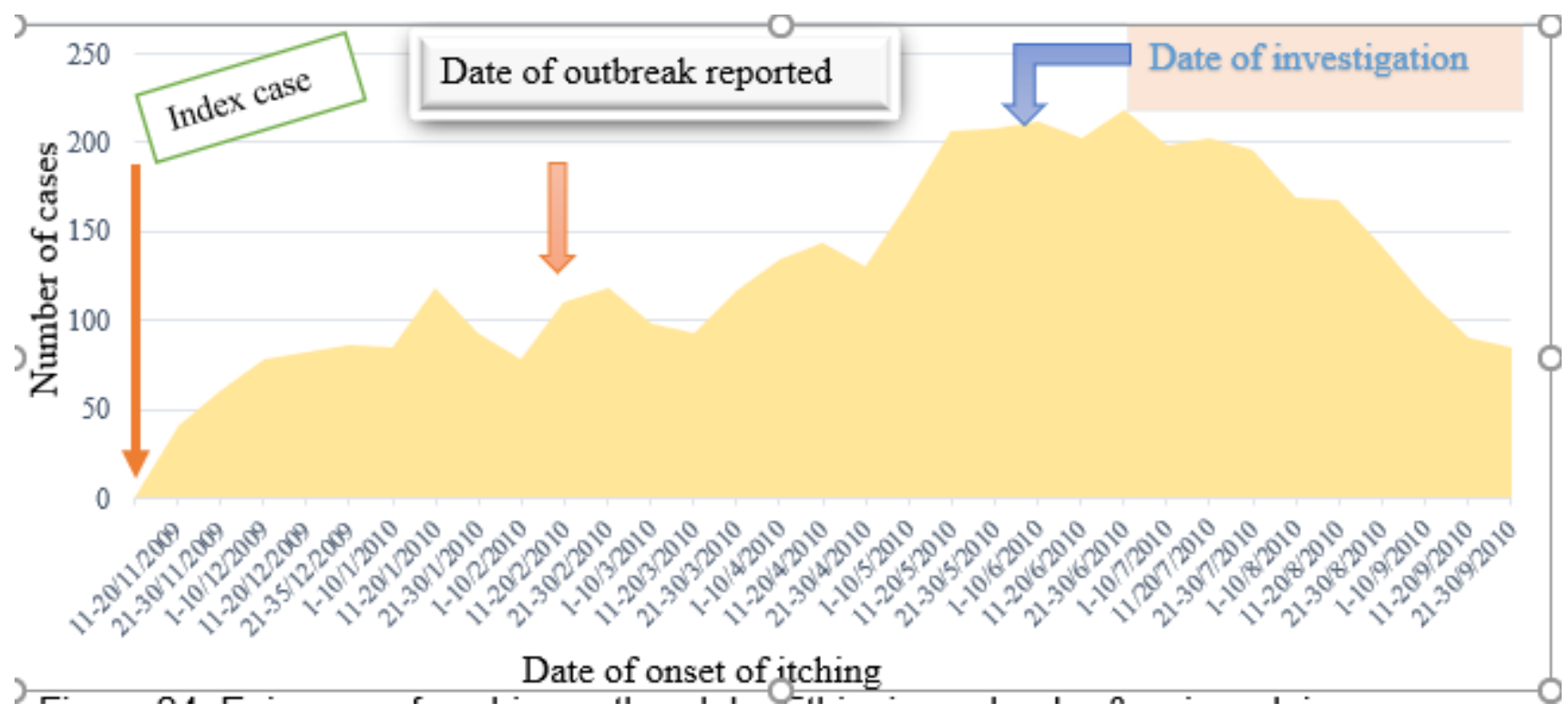

Figure 1

Epi curve of scabies outbreak by Ethiopian calendar \& epi week in Guna-begemidir district, Northwest Ethiopia, 2018

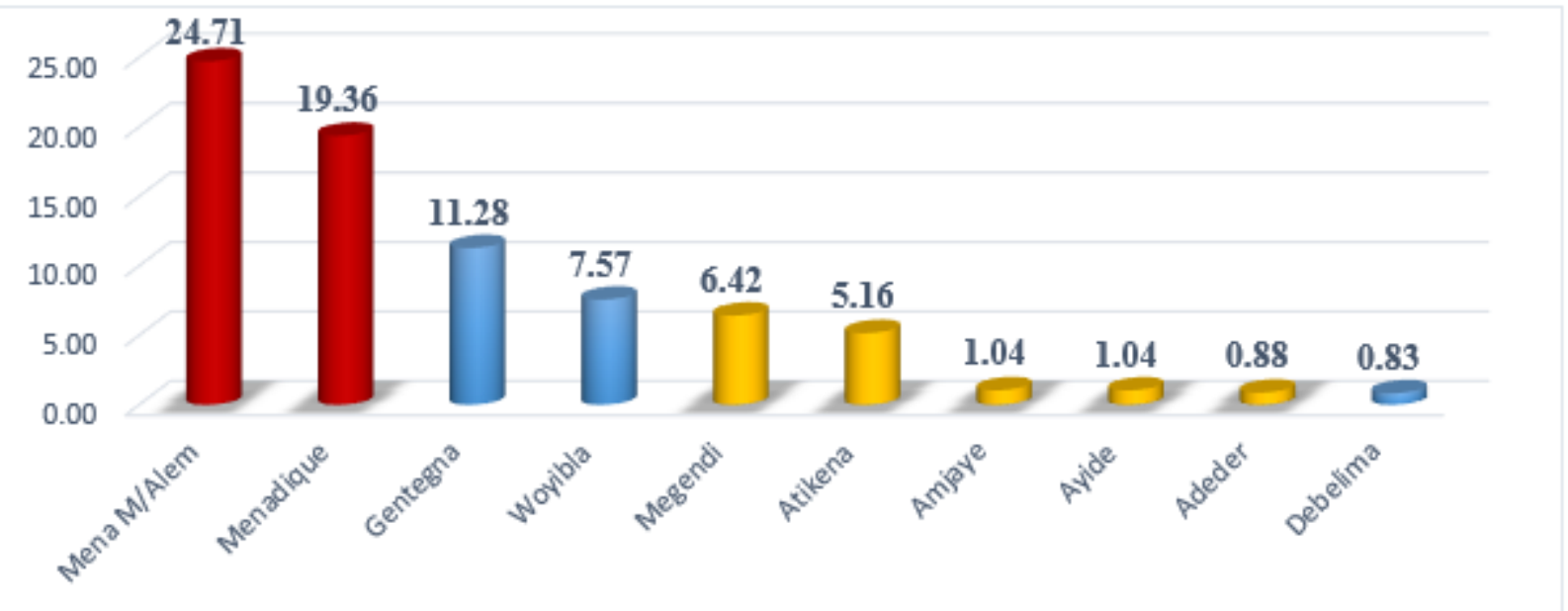

Figure 2

Distribution of scabies disease by attack rate by Kebeles of Guna-begemidir district, Northwest Ethiopia, 2018 


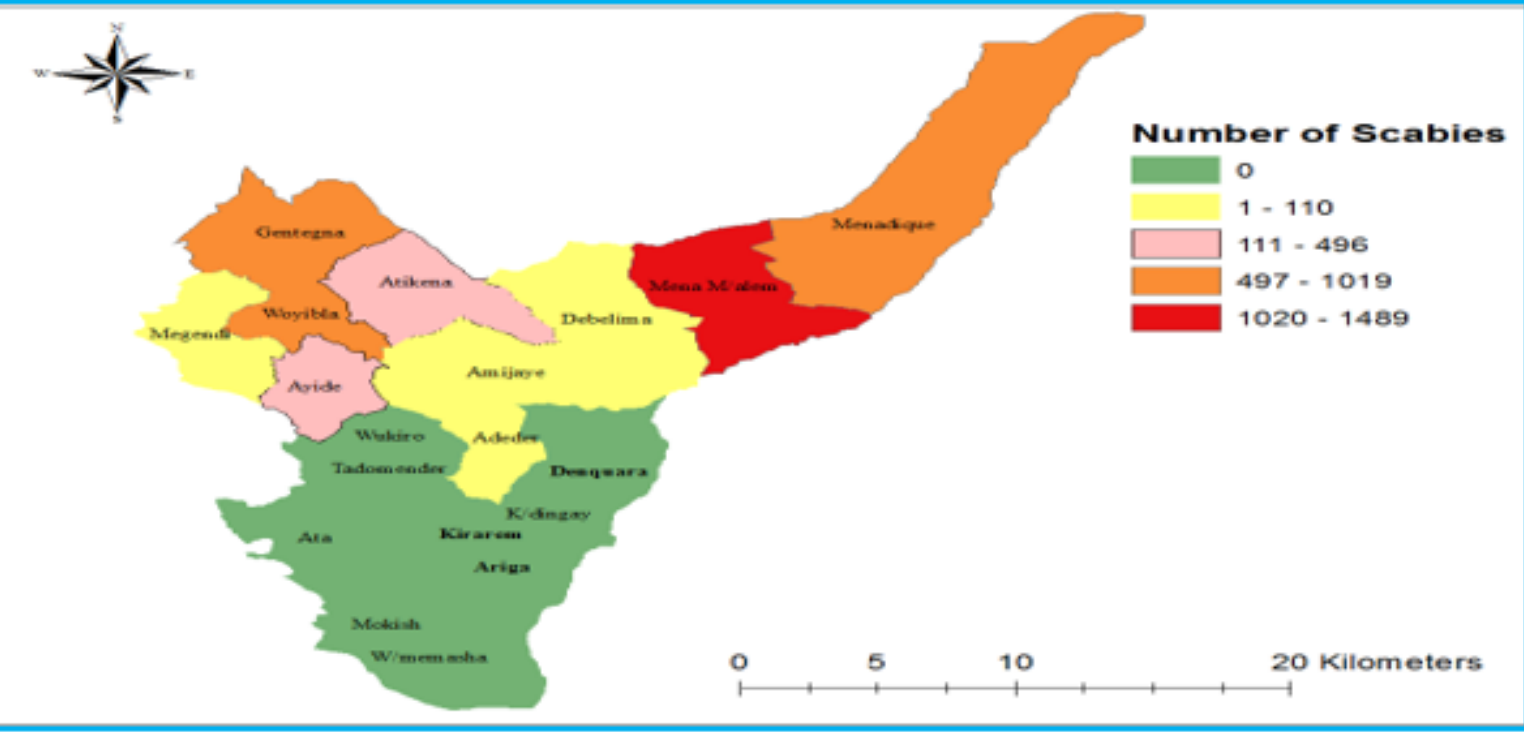

\section{Figure 3}

Choropleth map of scabies cases among Kebeles of Guna-begemidir district, Northwest Ethiopia, 2018

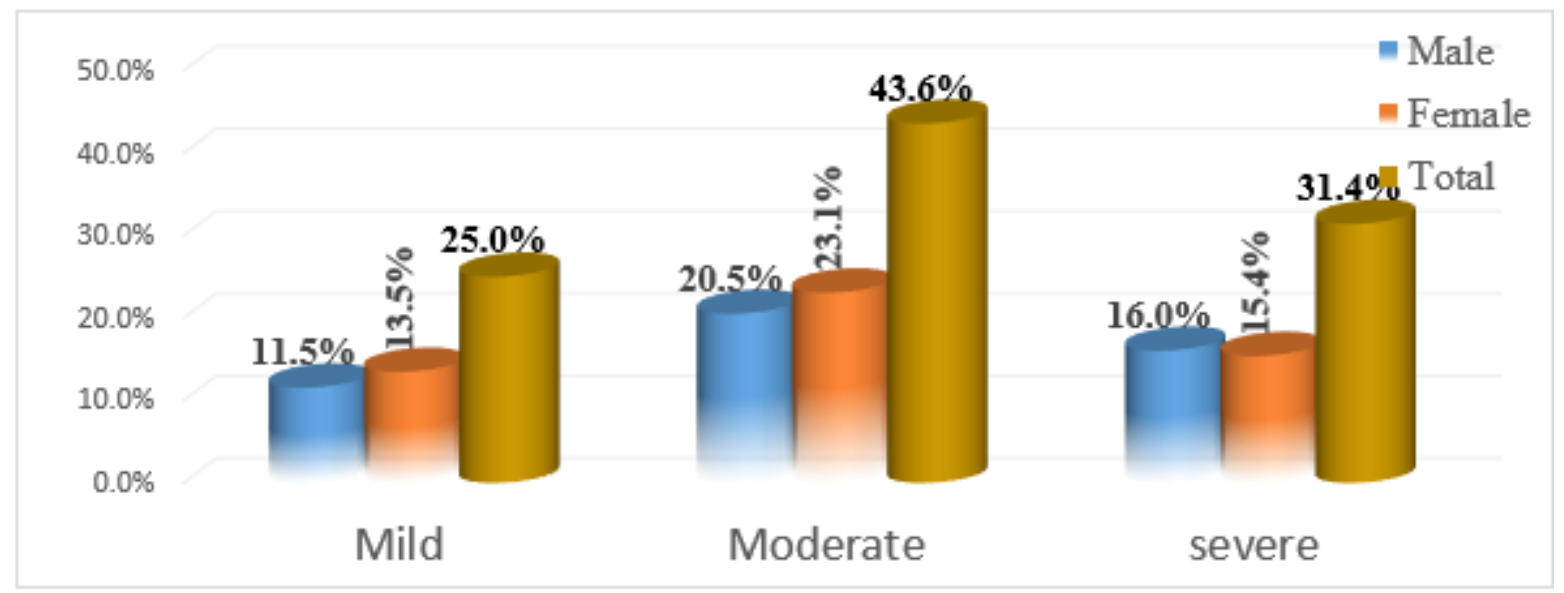

Figure 4

Level of scabies cases interviewed by age of Guna-begemidir district, Northwest Ethiopia, 2018 